\title{
RESPONSIBLITAS PIMPINAN UIN MAULANA MALIK IBRAHIM DALAM UPAYA MEMBERIKAN AKSES TERHADAP DIFFERENT ABILITY PERSPEKTIF UU NO. 8 TAHUN 2016 TENTANG PENYANDANG DISABILITAS
}

Oleh:

Erfaniah Zuhriah, S.Ag., M.H

\begin{abstract}
Abstrak
Penelitian in membahas mengenai responsiblitas pimpinan UIN Maulana Malik Ibrahim dalam upaya memberikan akses terhadap different ability perspektif UU No. 8 tahun 2016 Tentang Penyandang Disabilitas.. Jenis penelitian ini adalah penelitian empiris, yang berlokasi di kampus 1 UIN Maulana Malik Ibrahim Malang. Pendekatan penelitian yang digunakan adalah pendekatan pendekatan yuridis sosiologis, Pendekatan perundangundangan dan pendekatan konseptual. Jenis dan sumber data terdiri dari data primer, data sekunden dan data tersier. Teknik pengumpulan data primer dengan wawancara dan observasi langung di lapangan, data sekunder dengan studi kepustakaan dan data tersier diperoleh dar kamus umum, kamus hukum, ensikplodia dll. Teknik analisis data dilakukan dengan menggunakan metode "analisis kualitatif yuridis" yang bertitik tolak pada kerja "penalaran yuridis".

Dari hasil penelitian di dapat bahwa Respon pengambil kebijakan di UIN Maulana Malik Ibrahim dalam rangka memberikan akses terhadap penyandang disabilitas adalah mulai jajaran rektorat sampai dekanat sangat merespon baik tentang adanya UU No. 8 Tahun 2016 yang memberikan akses kepada para penyandang disabilitas untuk dapat memperoleh kesempatan yang untuk belajar di perguruan tinggi. Respon yang baik ini ditunjukkan dengan berbagai dukungan yang akan mereka berikan untuk mewujudkan UIN Maulana Malik Ibrahim Malang menjad kampus yang inklusi atau ramah terhadap mahasiswa penyandang disabilitas, bukti nyatanya adalah akan dimulai pada saat pembangunan kampus 3 UIN Maulana Malik Ibrahim Malang di Desa Tlekung Kota Batu Malang Jawa Timur.

Site plant kampus UIN Maulana Malik Ibrahim untuk mewujudkan kampus yang ingklusi dalam memberikan akses terhadap penyandang disabilitas perspektif UU No. 8 Tahun 2016 bahwa UIN Mulana Malik Ibrahim Malang sebagai institusi juga sudah menyusun perencanaan terutama terkait dengan pengembangan kampus. Penyusunan perencanaan pengembangan kampus UIN Maulana Malik Ibrahim yang ramah difabel akan dimulai pada saat membangun kampus 3. Ada beberapa tahapan perencanaan, yaitu perencanaan konstruksi, pengawasan dan fisik. Dalam tahapan perencanaan itu, site plan kampus UIN Maulana Malik Ibrahm ini ini sudah dirumukan sebagai bangunan yang ramah difabel artinya akan memberikan akses terhadap penyandang disabilitas, yang dimulai dari pemberian sarana dan prasarana.
\end{abstract}

Kata Kunci: Responsibilitas, Penyandang Disabilitas, Pimpinan UIN Maulana Malik Ibrahim

Abstract 
This study discusses the response of the leadership of UIN Maulana Malik Ibrahim in an effort to provide access to persons with disability perspective of law No. 8 year 2016 About persons with Disability.This type of research is empirical research, located on campus 1 UIN Maulana Malik Ibrahim of Malang. The research approach used is the juridical sociological approach, statue approach and conceptual approach. Types and sources of data consists of primary data, secondary data, and tertiary data material. Primary data collection techniques by interviews and observations directly in the field, secondary data by library study and tertiary data obtained from General dictionary, legal dictionary, ensiclopedia etc. Technique of data analysis is done using qualitative jurirical analysis method that focused on "juridical reasoning"

From the results of study it is known that response of policy makers in UIN Maulana Malik Ibrahim in order to provide access to persons with disability are very good response about the existence of the law No. 8 year 2016 which gives access to the persons with disability to be able to gain the opportunity to learn in College. A good response is shown with several supports they will provide to embody UIN Maulana Malik Ibrahim of Malang to became a campus of inclusion or friendly toward students with disability, it is shown with the begining of the construction of campus 3 UIN Maulana Malik Ibrahim of Malang in the village of Tlekung town of Batu, Malang in East Java.

Key Words : Responsibility, People with Disability, Leader of UIN Maulana Malik Ibrahim of Malang

\section{A. Pendahuluan}

Negara yang bermartabat adalah Negara yang menghormati, menghargai, memenuhi dan memberikan perlindungan bagi setiap warga negaranya tanpa kecuali. Isu tentang penyandang disabilitas atau orang-orang yang memiliki perbedaan kemampuan seringkali dikenal dengan istilah "difable" (differently abled people) atau sekarang dikenal sebagai "disabilitas" adalah masalah yang paling jarang mendapatkan perhatian dari Pemerintah maupun masyarakat.

Negara Republik Indonesia adalah Negara yang berdasarkan Pancasila dan UndangUndang Dasar Negara Republik Indonesia Tahun 1945 yang menghormati dan menjunjung tinggi harkat dan martabat manusia sehingga perlindungan dan pemajuan hak asasi manusia terhadap kelompok rentan khususnya penyandang disabilitas perlu ditingkatkan. Hal ini terlihat dalam Pasal 5 ayat (1), Pasal 11, Pasal 20, dan Pasal 28 I ayat (2) Undang-Undang Dasar Negara Republik Indonesia Tahun 1945.

Hak setiap warga negara adalah mendapatkan pendidikan yang layak dan tanpa diskriminasi. Hak pendidikan ini juga berlaku kepada orang berkebutuhan khusus atau penyandang cacat atau yang biasa disebut difabel (different ability).Dalam Undang Undang Dasar 1945 pasal 31 ayat 1 dan Undang-Undang Nomor 2 tahun 1989 tentang Sistem Pendidikan Nasional bab III ayat 5 dinyatakan bahwa setiap warganegara mempunyai 
kesempatan yang sama memperoleh pendidikan. Hal ini menunjukkan bahwa anak berkelainan berhak pula memperoleh kesempatan yang sama dengan anak lainnya (anak normal) dalam pendidikan.

Hak pendidikan merupakan bagian dari Hak Ekosob (Ekonomi, Sosial, Budaya). Negara mempunyai kewajiban (state obligation) untuk memenuhi (fulfill), menghormati (to respect), dan melindungi (to protect) setiap hak pendidikan yang dimiliki oleh setiap warga negaranya. Termasuk hak pendidikan untuk penyandang cacat. Pada pasal $28 \mathrm{C}$ Undangundang Dasar 1945 pun dikatakan bahwa setiap orang berhak mengembangkan diri melalui pemenuhan kebutuhan dasarnya, berhak mendapat pendidikan dan memperoleh manfaat dari ilmu pengetahuan dan teknologi, seni dan budaya, demi meningkatkan kualitas hidupnya dan demi kesejahteraan umat manusia, sehingga jelas disini kewajiban generik negara dalam pemenuhan hak pendidikan adalah memfasilitasi (to facilitate), memajukan (to promote), menyediakan (to provide).

Dengan disahkannya Rancangan Undang-undang (RUU) menjadi Undang-undang tentang Penyandang Disabilitas dalam rapat paripurna yang berlangsung pada Kamis. 17 Maret 2016 oleh Dewan Perwakilan Rakyat dan akan menjadi Undang-Undang 30 hari sejak disahkan DPR dengan atau tanpa tanda-tangan presiden, diharapkan bisa menjamin hak dan kesempatan penyandang disabilitas terpenuhi, mulai dari hak hidup, pekerjaan, pendidikan, hingga akses fasilitas.

UU Penyandang Disabilitas memberikan hak-hak bagi penyandang disabilitas yang terkait dengan pemenuhan hak dalam hal ekonomi, politik, sosial maupun budaya. Mereka juga dijamin haknya untuk memperoleh pekerjaan dan pendidikan di tengah masyarakat.

Penanganan pendidikan selama ini masih banyak yang belum memperhatikan faktor aksesibilitas fisik bagi penyandang disabilitas. Penanganan pendidikan bagi penyandang diasbilitas selama ini lebih banyak mengarah kepada penanganan pada konten pendidikan saja. Program-program yang ada masih kelihatan kepada penanganan non fisik seperti kurikulum, proses penanganan/pembelajaran dan penilaiannya. Jarang sekali lembaga pendidikan meingimpelentasikan peraturan tentang aksesibilitas bagi penyandang disabilitas. Bahkan sekolah-sekolah yang dirancang khusus untuk anak berkebutuhan khususpun tidak memperhatikan lingkungannya akses atau tidak terhadap penyandang disabilitas. Padahal sesuai peraturan perundang-undangan yang ada misalnya UU No. 28 tahun 2002 tentang bangunan gedung, lembaga pendidikan/sekolah termasuk kategori fasilitas umum yang harus mengakomodir aksesibilitas bagi penyandang disabilitas. Akses-akses lainnya seperti akses kursi roda, petunjuk untuk tunanetra, tiang-tiang bangunan masih belum terlihat. Begitu juga 
prinsip-prinsip bangunan dan lingkungan lainnya yang belum banyak diimplementasikan, termasuk di lembaga-lembaga pendidikan tinggi.

Terlebih lagi belum dibentuknya Unit Layanan Disabilitas yang merupakan suatu keharusan bagi penyelenggara pendidikan tinggi untuk mengadakannya. Karena di dalam UU No. 8 Tahun 2016 tentang Penyandang Disabilitas Pasal 42 dinyatakan bahwa Penyelenggara pendidikan tinggi yang tidak membentuk Unit Layanan Disabilitas dikenai sanksi administrative berupa:

a. Teguran tertulis;

b. Penghentian kegiatan pendidikan;

c. Pembekuan izin penyelenggaraan pendidikan; dan

d. Pencabutan izin penyelenggaraan pendidikan.

Mengingat pentingnya aksesibilitas fisik maupun non fisik bagi penyandang disabilitas dan pembentukan Unit Layanan Disabilitas serta masih minimnya implementasi dari peraturan perundang-undangan yang ada, maka menginspirasi peneliti untuk melakukan penelitian terkait "Responsiblitas Pimpinan UIN Maulana Malik Ibrahim Dalam Upaya Memberikan Akses Terhadaf Different Ability Perspektif UU No. 8 Tahun 2016 tentang Penyandang Disabilitas".

\section{B. Metodologi Penelitian}

Jenis penelitian dalam penelitian ini adalah yuridis empiris yang dengan kata lain adalah jenis penelitian hukum sosiologis dan dapat disebut pula dengan penelitian lapangan, yaitu mengkaji ketentuan hukum yang berlaku serta apa yang terjadi dalam kenyataannya di masyarakat. ${ }^{1}$ Atau dengan kata lain yaitu suatu penelitian yang dilakukan terhadap keadaan sebenarnya atau keadaan nyata yang terjadi di masyarakat dengan maksud untuk mengetahui dan menemukan fakta-fakta dan data yang dibutuhkan. Setelah data yang dibutuhkan terkumpul kemudian menuju kepada identifikasi masalah yang pada akhirnya menuju pada penyelesaian masalah.

Metode pendekatan yang digunakan dalam penelitian ini adalah pendekatan yuridis sosiologis, Pendekatan perundang-undangan (statute approach) dan pendekatan konseptual (conceptual approach). Pendekatan yuridis sosiologis adalah mengidentifikasi dan mengkonsepsikan hukum sebagai institusi sosial yang riil dan fungsional dalam sistem kehidupan yang mempola". ${ }^{2}$ Lokasi yang dijadikan tempat untuk melakukan penelitian ini

\footnotetext{
${ }^{1}$ Bambang Waluyo, Penelitian Hukum Dalam Praktek, (Jakarta, Sinar Grafika, 2002), hlm. 15

${ }^{2}$ Soerjono Soekanto, Pengantar Penelitian Hukum, (Jakarta: Penerbit Universitas Indonesia Press, 1986), hlm. 51.
} 
adalah Kampus I UIN Maulana Malik Ibrahim Malang di Jalan Gajayana No. 50 Malang. Sumber data yang digunakan dalam penelitian ini terdiri dari sumber data primer, sumber data sekunder dan sumber data tersier.

\section{Pembahsan}

\section{Pengertian Responsibilitas}

Responsibilitas (responsibility) merupakan konsep yang berkenaan dengan standar profesional dan kompetensi teknis yang dimiliki administrator (birokrasi publik) dalam menjalankan tugasnya. Seberapa jauh mereka melihat administrasi Negara (birokrasi publik) bersikap tanggap (responsive) yang lebih tinggi terhadap apa yang menjadi permasalahan, kebutuhan, keluhan dan aspirasi mereka. ${ }^{3}$ Sedangkan responsibilitas menurut Friedrich merupakan konsep yang berkenaan dengan standar professional dan kompetensi teknis yang dimiliki administrator publik untuk menjalankan tugasnya. ${ }^{4}$ Islmay mengatakan bahwa responsibilitas subyektif lebih mengedepankan nilai-nilai etis dan kemanusiaan yang terangkum dalam equity (hak menurut keadilan/kewajaran), equality (persamaan hak), fairness (kejujuran) untuk memberikan pelayanan kepada masyarakat dan tugas administrasi lainnya. ${ }^{5}$

Responsibilitas adalah menyangkut pelaksanaan kegiatan organisasi publik sesuai dengan prinsip-prinsifp administrasi yang benar atau sesuai dengan kebijakan organisasi baik secara eksplisit maupun secara implisit ${ }^{6}$. Prinsip responsibilitas adalah kesesuaian atau kepatuhan di dalam pengelolaan perusahaan terhadap prinsip korporasi yang sehat serta peraturan perundangan yang berlaku. ${ }^{7}$

\section{Jenis-Jenis Responsibilitas dan Model Responsibilitas}

Dua jenis responsibilitas yang dapat ditemukan adalah terkadang disebut sebagai responsibilitas subjektif dan responsibilitas objektif. Responsibilitas obyektif harus dilakukan

\footnotetext{
${ }^{3}$ Amin Rahmanurrasyid, Akuntabilitas Dan Transparansi Dalam Pertanggung Jawaban Pemerintahan Daerah Untuk Mewujudkan Pemerintahan Yang Baik, (Tesis Tahun 2008), hlm. 81

${ }^{4}$ Pendi, Responsibilitas Pelayanan Publik Dalam Kepemimpinan Integrative Terhadap Pembangunan Daerah, (Makassar: Skripsi Unhas: 2011), hlm. 25

5 ibid

${ }^{6}$ Agus Dwiyanto, Mewujudkan Good Governace Melalui Pelayanan Publik, (Yogyakarta: Gadjah Mada, 2005), hlm. 8

${ }^{7}$ Mas Achmad Daniri, Good Corporate Governance: Konsep Dan Penerapannya Dalam Konteks Indonesia, (Jakarta: Ray Indonesia, 2005), hlm 9
} 
dengan tuntutan dari luar diri kita, sedangkan responsibilitas subjektif yaitu terfokus pada hal-hal yang membuat seseorang merasa bertanggung jawab. ${ }^{8}$

Pada umumnya model responsibilitas administrasi diketahui berkembang dari kombinasi terhadap komponen perilaku responsibilitas dan komponen dari etika individu. Beberapa model mengenali kewajiban dari organisasi dan peraturan dari warga yang harus lebih diutamakan. Model responsibilitas administrasi dibagi menjadi dua aspek yaitu komponen perilaku dan etika. Hal ini kemudian dapat dilihat dari table beriku: ${ }^{9}$

Tabel 1

Model Responsibilitas Administrasi

\begin{tabular}{|l|l|}
\hline \multicolumn{1}{|c|}{ Perilaku responsibilitas } & \multicolumn{1}{c|}{ Etika Individu } \\
\hline 1. Kebutuhan individu & 1. Delimitasi dan transcendence \\
2. Struktur organisasi & organisasi. \\
3. Budaya organisasi & 2. Hukum dan mekanisme \\
4. Harapan masyarakat & kelembagaan untuk \\
& membatasi kekuasaan \\
& organisasi. \\
& 3. Kesadaran diri. \\
\hline
\end{tabular}

\section{Pengertian Penyandang Disabilitas}

Menurut Undang-Undang Nomor 19 Tahun 2011 Tentang Pengesahan Hak-Hak Penyandang Disabilitas, penyandang disabilitas yaitu orang yang memiliki keterbatasan fisik, mental, intelektual atau sensorik dalam jangka waktu lama yang dalam berinteraksi dengan lingkungan dan sikap masyarakatnya dapat menemui hambatan yang menyulitkan untuk berpartisipasi penuh dan efektif berdasarkan kesamaan hak. ${ }^{10}$

Menurut Pasal 1 angka 1 UU No. 8 Tahun 2016 tentang Penyandang Disabilitas, Penyandang disabilitas adalah setiap orang yang mengalami keterbatasan fisik, intelektual, mental, dan/atau sensorik dalam jangka waktu lama yang dalam berinteraksi dengan lingkungan dapat mengalami hambatan dan kesulitan untuk berpartisipasi secara penuh dan efektif dengan warga negara lainnya berdasarkan kesamaan hak.

Orang berkebutuhan khusus (disabilitas) adalah orang yang hidup dengan karakteristik khusus dan memiliki perbedaan dengan orang pada umumnya. Karena karakteristik yang berbeda inilah memerlukan pelayanan khusus agar dia mendapatkan hakhaknya sebagai manusia yang hidup di muka bumi ini. Orang berkebutuhan khusus memiliki

\footnotetext{
${ }^{8}$ Terry L.Cooper, The Responsible Administrator : an approach to ethics for the administrative role, (United State : Jossey Bay, 1998), hlm. 66

${ }^{9}$ Ibid., hlm. 48-49

${ }^{10}$ Undang-Undang Nomor 19 Tahun 2011 Tentang Pengesahan Hak-Hak Penyandang Disabilitas
} 
defenisi yang sangat luas, mencakup orang-orang yang memiliki cacat fisik, atau kemampuan IQ (Intelligence Quotient) rendah, serta orang dengan permasalahan sangat kompleks, sehingga fungsi-fungsi kognitifnya mengalami gangguan.

Di Indonesia, terminologi lain yang digunakan untuk menyebut "difable" ini antara lain adalah "penyandang cacat", "orang berkelainan", atau "orang tidak normal”. Istilah tersebut sebenarnya tidak "bebas nilai", artinya ada konsepsi nilai tertentu yang telah dipaksakan oleh sekelompok masyarakat tertentu yang "melabelkan" dan mendominasi kelompok masyarakat lain. Peristilahan ini berpengaruh secara langsung terhadap perlakuan masyarakat maupun pemerintah terhadap keberadaan "difable" secara menyeluruh. Namun demikian, konsepsi tersebut bisa pula berbeda dan berubah secara historis sesuai perkembangan yang terjadi dalam masyarakat maupun Negara. ${ }^{11}$

\section{Ragam Penyandang Disabilitas}

Terdapat beberapa ragam orang dengan kebutuhan khusus/disabilitas. Ini berarti bahwa setiap penyandang disabilitas memiliki definisi masing-masing yang mana kesemuanya memerlukan bantuan untuk tumbuh dan berkembang secara baik. Ragam penyandang disabilitas meliputi: ${ }^{12}$

a. Penyandang Disabilitas fisik, adalah terganggunya fungsi gerak, antara lain amputasi, lumpuh layuh atau kaku, paraplegi, celebral palsy (CP), akibat stroke, akibat kusta, dan orang kecil

b. Penyandang disabilitas Intelektual, adalah terganggunya fungsi pikir karena tingkat kecerdasan di bawah rata-rata, antara lain lambat belajar, disabilitas grahita dan down syndrom.

c. Penyandang disabilitas mental, adalah terganggunya fungsi pikir, emosi, dan perilaku, antara lain: (a). psikososial di antaranya skizofrenia, bipolar, depresi, anxietas, dan gangguan kepribadian; dan (b). disabilitas perkembangan yang berpengaruh pada kemampuan interaksi sosial di antaranya autis dan hiperaktif.

d. Penyandang disabilitas sensorik, adalah terganggunya salah satu fungsi dari panca indera, antara lain disabilitas netra, disabilitas rungu, dan/atau disabilitas wicara.

\footnotetext{
${ }^{11}$ Risnawati Utami, Konvensi Tentang Hak-Hak Penyandang Disabilitas: Dalam Perspektif Kebijakan Publik Di Indonesia, Makalah Untuk Intermediate Human Rights Training Bagi Dosen Hukum Dan HAM di Balikpapan, diselenggaakan atas Kerjasama PUSHAM UII dengan Norwegian Centere for Human Rights, 2012.

${ }^{12}$ Pasal 4 ayat (1) UU No. 8 Tahun 2016 tentang Penyandang Disabilitas
} 
Ragam Penyandang Disabilitas dapat dialami secara tunggal, ganda atau multi ${ }^{13}$ dalam jangka waktu lama ${ }^{14}$ yang ditetapkan oleh tenaga medis sesuai dengan ketentuan peraturan perundang-undangan. ${ }^{15}$

Menurut Convetion On The Rights of Persons With Disabilities (Konvensi Mengenai Hak-Hak Penyandang Disabilitas) yang telah disahkan dengan Undang-Undang Nomor 19 Tahun 2011 tentang Pengesahan Convention On The Rights Of Persons With Disabilities (Konvensi Mengenai Hak-Hak Penyandang Disabilitas), penyandang disabilitas termasuk mereka yang memiliki keterbatasan fisik, mental, intelektual, atau sensorik dalam jangka waktu lama dimana ketika berhadapan dengan berbagai hambatan, hal ini dapat mengahalangi partisipasi penuh dan efektif mereka dalam masyarakat berdasarkan kesetaraan dengan yang lainnya. Konvensi ini tidak memberikan batasan tentang penyandang cacat. Dalam konvensi ini penyandang cacat disebut sebagai penyandang disabilitas.

Adapun jenis dan penyebab kecacatan bisa disebabkan oleh berbagai faktor yaitu: ${ }^{16}$

a. Cacat didapat (Acquired), penyebabnya bisa karena kecelakaan lalu lintas, perang/konflik bersenjata atau akibat penyakit-penyakit kronis.

b. Cacat bawaan/sejak lahir (Congenital), penyebabnya antara lain karena kelainan pembentukan organ-organ (organogenesis) pada masa kehamilan, karena serangan virus, gizi buruk, pemakaian obat-obatan tak terkontrol atau karena penyakit menular seksual.

\section{Hak Atas Pendidikan Bagi Penyandang Disabilitas}

Hak dalam Kamus Besar Bahasa Indonesia menyebutkan bahwa hak adalah (1) yang benar, (2) milik kepunyaan, (3) kewenangan, (4) kekuasaan untuk berbuat sesuatu, (5) kekuasaan untuk berbuat sesuatu atau untuk menuntut sesuatu, dan (6) derajat atau martabat. ${ }^{17}$ Pengertian yang luas tersebut mengandung prinsip bahwa hak adalah sesuatu yang oleh sebab itu seseorang (pemegang) pemilik keabsahan untuk menuntut sesuatu yang dianggap tidak dipenuhi atau diingkari. Seseorang yang memegang hak atas sesuatu, maka orang tersebut dapat melakukan sesuatu tersebut sebagaimana dikehendaki, atau sebagaimana keabsahan yang dimilikinya. Kewajiban dasar manusia adalah seperangkat kewajiban yang

${ }^{13}$ Yang dimaksud dengan "Penyandang Disabilitas ganda atau multi" adalah Penyandang Disabilitas yang mempunyai dua atau lebih ragam disabilitas, antara lain disabilitas rungu-wicara dan disabilitas netra-tuli

${ }^{14}$ Yang dimaksud dengan "dalam jangka waktu lama" adalah jangka waktu paling singkat 6 (enam) bulan dan/atau bersifat permanen

${ }^{15}$ Pasal 4 ayat (2) UU No. 8 Tahun 2016 tentang Peyandang Disabilitas

${ }^{16}$ Sapto Nugroho, Risnawati Utami, Meretas Siklus Kecacatan-Realitas Yang Terabaikan, (Surakarta: Yayasan Talenta, 2005), hlm. 114.

${ }^{17}$ Poerwardarminta, Kamus Besar Bahasa Indonesia, (Jakarta; Balai Pustaka, 2001), hlm.174 
apabila tidak dilaksanakan tidak memungkinkan terlaksananya dan tegaknya hak asasi manusia. $^{18}$

Pasal 1 ayat (1) Undang-Undang Nomor 20 Tahun 2003, mendefinisikan pendidikan sebagai usaha sadar dan terancana untuk mewujudkan suasana belajar dan proses pembelajaran agar peserta didik secara aktif mengembangkan potensi dirinya untuk memiliki kekuatan spiritual keagamaan, pengendalian diri, kepribadian, kecerdasan, akhlak mulia serta keterampilan yang diperlukan dirinya, masyarakat bangsa dan negara.

Penyediaan fasilitas umum yang akseibel bagi penyandang disabilitas merupakan bentuk implementasi layanan kepada semua lapisan masyarakat yang adil, bermutu dan tanpa diskriminasi.

Fasilitas umum yang aksesibel bagi penyandang disabilitas sudah barang tentu tidak akan mengurangi kebermanfaatannya bagi orang lain, justu akan menambah manfaat juga bagi orang lain yang tidak mengalami disabilitas. Secara prinsip, jika penyandang disabilitas saja bisa mempergunakan fasilitas umum tersebut dengan mudah dan aman, tentu bagi orang lain yang tidak mengalami disabilitas akan lebih aksesibel. Secara garis besar, aksesibilitas bagi penyandang disabilitas menurut kegunaannya dikategorikan ke dalam dua jenis, yaitu (1) fasilitas yang bisa digunakan oleh siapa saja, tidak hanya penyandang disabilitas yang mempergunakannya, contohnya trotoar, selasar, life, dsb. (2) fasilitas yang hanya dipergunakan oleh penyandang disabilitas saja, orang yang tidak menyandang disabilitas tidak boleh mempergunakannya, contohnya ada beberapa fasilitas yang khusus disediakan oleh penyandang disabilitas seperti wc, tempat parkir, hidrolik di bus maupun di bangunan sebagai pengganti tangga di gedung bertingkat, jalan dengan kemeringan maksimal 30\%, dll.

Hukum di Indonesia telah banyak mengatur tentang sisi-sisi layanan kehidupan di segala bidang. Telah banyak peraturan perundangan-udangan ditetapkan baik oleh lembaga legislative maupun lembaga eksekutif. Undang-Undang nomor 28 tahun 2002 tentang Bangunan Gedung. Pasal 27 ayat 2 yaitu Kemudahan hubungan ke, dari, dan di dalam bangunan gedung sebagaimana dimaksud dalam ayat (1) meliputi tersedianya fasilitas dan aksesibilitas yang mudah, aman, dan nyaman termasuk bagi penyandang cacat dan lanjut usia.

Kemudian diperjelas lagi dalam pasal 31 UU No. 8 Tahun 2002, menyebutkan : (1) Penyediaan fasilitas dan aksesibilitas bagi penyandang cacat dan lanjut usia sebagaimana dimaksud dalam Pasal 27 ayat (2) merupakan keharusan bagi semua bangunan gedung,

\footnotetext{
${ }^{18}$ Pasal 1 angka 2 Undang-Undang Nomor 39 Tahun 1999 tentang Hak Asasi Manusia
} 
kecuali rumah tinggal. (2) Fasilitas bagi penyandang cacat dan lanjut usia sebagaimana dimaksud dalam ayat (1), termasuk penyediaan fasilitas aksesibilitas dan fasilitas lainnya dalam bangunan gedung dan lingkungannya. (3) Ketentuan mengenai penyediaan aksesibilitas bagi penyandang cacat dan lanjut usia sebagaimana dimaksud dalam ayat (1) dan ayat (2) diatur lebih lanjut dengan Peraturan Pemerintah.

Di bidang pendidikan, Yaitu pada Pasal 15 Undang-Undang No. 20 tahun 2003 tentang Sistem Pendidikan Nasional yang berbunyi "Pendidikan khusus merupakan penyelenggaraan pendidikan untuk peserta didik yang berkelainan atau peserta didik yang memiliki kecerdasan luar bisaa yang diselenggarakan secara inklusif atau berupa satuan pendidikan khusus pada tingkat pendidikan dasar dan menengah". Undang-undang tersebut, memberikan pilihan bagi penyandang disabilitas usia sekolah (disebut Anak Berkebutuhan Khusus/ABK) dapat menempuh pendidikan baik di sekolah regular (paradigma pendidikan inklusif) maupun di SLB (satuan pendidikan khusus). Ketentuan lebih lanjut tentang pelaksanaan pendidikan inklusif telah diatur dalam Permendiknas No. 70 tahun 2009.

Pasal 10 UU No. 8 Tahun 2016, menyebutkan bahwa Hak pendidikan untuk Penyandang Disabilitas meliputi hak:

a. Mendapatkan pendidikan yang bermutu pada satuan pendidikan di semua jenis, jalur, dan jenjang pendidikan secara inklusif dan khusus;

b. Mempunyai Kesamaan Kesempatan untuk menjadi pendidik atau tenaga kependidikan pada satuan pendidikan di semua jenis, jalur, dan jenjang pendidikan;

c. Mempunyai Kesamaan Kesempatan sebagai penyelenggara pendidikan yang bermutu pada satuan pendidikan di semua jenis, jalur, dan jenjang pendidikan; dan

d. Mendapatkan Akomodasi yang Layak sebagai peserta didik.

\section{Hak- Hak Penyandang Disabilitas Dalam Beberapa Peraturan Perundang-Undangan}

Berbagai peraturan perundang-undangan yang memberikan jaminan aksesibilitas bagi penyandang disabilitas, diantaranya sebagai berikut :

a Undang-Undang Dasar Republik Indonesia Tahun 1945, dalam Pasal 28 D ayat (1) : "Setiap orang berhak atas pengakuan, jaminan, perlindungan, dan kepastian hukum yang adil serta perlakuan yang sama di hadapan hukum.“

b Undang-Undang Nomor 4 Tahun 1997 tentang Penyandang Cacat

c Undang-Undang Nomor 19 Tahun 2011 tentang Pengesahan Convention on the Rights of Persons with Disabilities Convention on the Rights of Persons with Disabilities (CRPD) yaitu konvensi 8 tentang Hak-hak Difabel atau Penyandang Disabilitas, telah 
diratifikasi oleh Negara Republik Indonesia dalam Undang-Undang Negara Republik Indonesia Nomor 19 Tahun 2011 tentang Pengesahan CRPD.

d. Undang-Undang Nomor 25 Tahun 2009 tentang Pelayanan Publik Sejalan dengan Undang-Undang Nomor 4 Tahun 1997 tentang Penyandang Cacat yang dijelaskan sebelumnya, dalam Undang-Undang Nomor 25 Tahun 2009 tentang Pelayanan Publik secara tegas menyatakan bahwa pelayanan publik memiliki beberapa asas yang mengamanahkan kemudahan aksesibilitas kepada penyandang disabilitas.

e. Undang-Undang Nomor 28 Tahun 2002 tentang Bangunan Gedung. Pengaturan mengenai hak-hak penyandang disabilitas dalam undang- undang ini diatur dalam Pasal 27 Undang- Undang Nomor 28 Tahun 2002 tentang Bangunan Gedung yang berbunyi : kemudahan hubungan ke, dari, dan di dalam bangunan gedung sebagaimana dimaksud dalam ayat (1) meliputi tersedianya fasilitas dan aksesibilitas yang mudah, aman, dan nyaman termasuk bagi penyandang cacat dan lanjut usia. ${ }^{19}$

f. Peraturan Pemerintah Nomor 43 Tahun 1998 tentang Upaya Peningkatan Kesejahteraan Sosial Penyandang Cacat Pengaturan aksesibilitas pelayanan lebih lanjut bagi penyandang disabilitas secara lebih jelas dan rinci diatur dalam Peraturan Pemerintah Nomor 43 Tahun 1998 tentang Upaya Peningkatan Kesejahteraan Sosial Penyandang Cacat.

g. Peraturan Menteri Pekerjaan Umum Nomor 30/PRT/M/2006 Penyandang disabilitas mempunyai hak sepenuhnya untuk diberi kemudahan akses seluruh fasilitas di bangunan umum maupun di lingkungan sekitar seperti orang lain. Peraturan Menteri Pekerjaan Umum Nomor 30/PRT/M/2006 merupakan tindak lanjut dari Pasal 18 Peraturan Pemerintah Nomor 43 Tahun 1998 Tentang Upaya Peningkatan Kesejahteraan Penyandang Cacat yang berbunyi : Standardisasi penyediaan aksesibilitas sebagaimana dimaksud dalam Pasal 10 sampai dengan Pasal 17 ditetapkan oleh Menteri dan Menteri lain baik secara bersama-sama maupun sendirisendiri sesuai dengan tugas dan fungsinya masing-masing. ${ }^{20}$

\section{Respon Pengambil Kebijakan di UIN Maulana Malik Ibrahim Dalam Rangka Memberikan Akses Terhadap Penyandang Disabilitas}

UIN Maulana Malik Ibrahim Malang sebagai sebuah perguruan tinggi Islam mengembangkan konsep Ulul Albab yang dalam praktiknya dikembangkan menjadi tiga

\footnotetext{
${ }^{19}$ Lihat Pasal 27 ayat (2) Undang-Undang Nomor 28 Tahun 2002 tentang Bangunan Gedung

20 Lihat Pasal 18 Peraturan Pemerintah Nomor 43 Tahun 1998 Tentang Upaya Peningkatan Kesejahteraan Penyandang Cacat
} 
bentuk perilaku ideal yaitu dzikir, fikr, dan amal sholeh. Konsep Ulul Albab tersebut diharapkan bisa memberikan penjelasan tentang filosofi, identitas, arah yang ingin dicapai, budaya, pendekatan yang dikembangkan serta hal lain yang dipandang penting agar perguruan tinggi Islam ini dikenal secara mendalam, baik oleh warganya sendiri maupun pihak lain. ${ }^{21}$

UIN Maulana Malik Ibrahim Malang sebagai salah satu perguruan tinggi Islam terkemuka di Indonesia ini harus siap melaksanakan dan harus merespon dengan positif UU No.8 Tahun 2016 tentang Penyandang Disabilitas yang sudah disahkan dan diundangkan pada bulan Juli 2016 ini, artinya UIN Maulana Malik Ibrahim Malang ini harus mulai berbenah dalam segala hal untuk merespon aturan tersebut. Untuk menerapkan aturan itu, diperlukan komitmen seluruh civitas akademika untuk mewujudkan kampus UIN Maulana Malik Ibrahim Malang sebagai salah satu kampus yang ramah difabel.

Untuk masalah akses ini, ketersediaan sarana dan prasarana yang ramah difable (penyandang cacat) saat ini masih sangat terbatas di Indonesia pada umumnya, dan Kampus UIN Maulana Malik Ibrahim Malang khususnya. Akses terhdap difable (pencandang disabilitas) yang dijanjikan pemerintah dalam Undang-Undang Nomor 8 Tahun 2016 tentang Penyandang Disabilitast pada prakteknya tetap saja belum mempermudah akses pergerakan mereka. Beberapa sarana dan prasarana yang dibangun dengan mempertimbangkan difable (penyandang disabilitas) bahkan pada pelaksanaannya masih saja menyulitkan mereka.

Berdasarkan temuan Sidiq yang melakukan penelitian di beberapa perguruan tinggi di Yogyakarta, terdapat beberapa perguruan tinggi yang belum menunjukkan keberpihakannya kepada penyandang disabilitas. Civitas akademika belum bisa menerima penyandang disabilitas sebagai bagian dari civitas akademiknya karena berbagai alasan, misalnya, antara lain, mereka belum siap menyediakan fasilitas yang menunjang proses belajar-mengajar bagi penyandang disabilitas dan menyangsikan kemampuan akademik mereka karena keterbatasan fisik yang melekat. ${ }^{22}$

Akses bagi difable (penyandang disabilitas) dititikberatkan pada ketersediaan dan kelayakan fasilitas yang ramah difable (penyandang disabilitas), dimana perencana adalah subjek perancang yang bertanggung jawab terhadap akses difable (penyandang disabilitas) sebagai warga negara yang juga memiliki hak yang sama dengan warga Negara lain.

\footnotetext{
${ }^{21}$ Imam Suprayogo, Tarbiyah Ulul Albab: Dzikir, Fikr, dan Amal Shaleh, (Malang: Universitas Islam Negeri Malang, 2004), hlm. 7

22 D.M. Sidiq, “Mahasiswa Difabel di Perguruan Tinggi," dalam Sekar Ayu Aryani (ed.), Desain Pembelajaran Sensitif Difabel,( Yogyakarta: IIS PPS UIN, 2007), hlm. 13-15
} 
Imron $^{23}$ menyatakan bahwa kebijakan-kebijakan pendidikan tersebut dapat diklasifikasikan ke dalam dua bentuk yaitu, pertama, kebijakan yang berbentuk Peraturan Pemerintah yang memberikan kesempatan pendidikan bagi penyandang disabilitas, seperti yang tercantum dalam kebijakan internasional Declaration of Human Rights (1989), Convention on the Rights of the Child (1989), Life Long Education-Education for All (Bangkok, 1991), Dakkar Statement (1990), Standard Rules on the Equalization of Opportunities for Person with Disabilities (Resolusi PBB Nomor 48/46 Tahun 1993), Salamanca Statement (1994), The Four Pillars of Education (Unesco, 1997), ASEAN Pacific Decade for Disabled (Biwako, 2002), Deklarasi Bukit Tinggi (2005), dan The Convention on The Human Rights of Person with Disabilities (Resolusi PBB Nomor 61/106 Tahun 2006). Sedangkan kebijakan yang tertuang dalam peraturan nasional tercantum dalam UUD 1945 (amandemen) Pasal 131 Ayat 1 dan 2, Peraturan Pemerintah Nomor 72 Tahun 1991 tentang Pendidikan Luar Biasa, UU Nomor 20 Tahun 2003 tentang Sistem Pendidikan Nasional (Sisdiknas) Pasal 3, Pasal 5, Pasal 32, Pasal 51, Pasal 52, dan Pasal 53. UU Nomor 4 Tahun 1997 Pasal 7 tentang Penyandang Cacat.

Kedua, kebijakan yang berbentuk sikap pemerintah dalam mendukung terselenggaranya pendidikan bagi penyandang disabilitas, terutama pejabat yang mengurus pendidikan, dalam hal ini Menteri Pendidikan dan Menteri Agama. Kebijakan ini terdiri dari dua macam, yaitu: 1) berupa sikap resmi, misalnya berbentuk Surat Edaran Dirjen Dikdasmen Depdiknas Nomor: 380/e.C8/MN/2003 Tanggal 20 Januari 2003 atau Surat Keputusan Menteri Agama yang berkaitan dengan pendidikan penyandang disabilitas, unitunit yang menangani penyandang disabilitas, penyediaan fasilitas pendidikan dan penyediaan sarana dan prasarana pendidikan bagi penyandang ketunaan; 2) berupa sikap tidak resmi, misalnya komentar atau pernyataan Menteri Pendidikan atau Menteri Agama melalui media massa yang berkaitan dengan persamaan dan kesempatan pendidikan bagi penyandang disabilitas sehingga masyarakat dapat mengetahui ${ }^{24}$

Dengan diundangkannya UU No. 8 Tahun 2016 tentang Penyandang Disabilitas, selain mengamanahkan untuk menyediakan sarana dan prasarana yang ramah difable, perguruan tinggi juga diharuskan untuk membentuk Unit Layanan Disabilitas. Pasal 42 UU Penyandang Disabilitas ini menyatakan bahwa Penyelenggara pendidikan tinggi yang tidak membentuk Unit Layanan Disabilitas dikenai sanksi administrative berupa:

${ }^{23}$ A. Imron, Kebijakan Pendidikan di Indonesia: Proses, Produk, dan Masa Depannya, (Jakarta: Bumi Aksara, 1996), hlm. 24-25

${ }^{24}$ Ibid. 
a. Teguran tertulis;

b. Penghentian kegiatan pendidikan;

c. Pembekuan izin penyelenggaraan pendidikan; dan

d. Pencabutan izin penyelenggaraan pendidikan.

Untuk merespon itu, Dekan Fakultas Syariah UIN Maulana Malik Ibrahim Malang Dr. Roibin, M.HI menyatakan bahwa implementasi tentang UU No. 8 Tahun 2016 tentang Penyandang Disabilitas ini sangat relevan dengan ajaran Islam, yaitu dakwah dengan salah satunya dengan memberikan akses kepada kaum difabel, tentu dengan adannya UU ini kami dari pihak pimpinan setuju dan mendukung dengan langkah langkah konkrit dalam benuk kebijakan universitas lewat pendidikan ini. Menurut saya seluruh pimpinan harus respon, terlebih ada pasal yang menyatakan akan mencabut izin oprasional lembaga pendidikan jika tidak menfasilitasi kaum difabel ini dan membentuk layanan difabel. ${ }^{25}$

Lebih lanjut Dekan Fakultas Syariah ini menjelaskan tentang langkah konkrit yang harus dilakukan adalah sosialisasi terhadap UU Penyandang Disabilitas ini yang dikomandani oleh Wakil Rektor 1 UIN Maulana Malik Ibrahim, dan hasil penelitian ini harus bisa disosialisasikan kepada seluruh civitas akademik terutama pucuk pimpinan universitas dan dekanat. Secara normatif UU ini melegitimasi untuk lebih perhatian kepada kaum difabel yang dalam Islam disebut dengan mustadafin. Langkah selanjutnya adalah dengan merealisasikan dalam bentuk konkrit yang mungkin bisa dimulai dengan pembangunan kampus 3 yang berlafal bismillah ini, baik sarana prasarana mulai harus difikirkan. Yang jelas, kami selaku pimpinan sangat mendukung dan mengakomodir dari disahkannya UU difabel ini dengan bentuk nyata melalui kebijakan, sosialisasi dan realisasi di lapngan. Mulai dari sarana prasarananya dan kurikulumnya. ${ }^{26}$

Wakil Rektor 1 UIN Maulana Malik Ibrahim Malang merespon dengan sangat positif UU Penyandang Disabilitas ini, dimana kata beliau pendidikan inklusi harus diterapkan dan sesuai dengan visi kita, yaitu tidak membedakan pendidikan ditinjau dari status sosial, gender maupun penyandang cacat. Pendidian inklusi juga sesuai dengan nafas kita yang tidak boleh membedakan. Ini terbukti dengan pada waktu seleksi masuk perguruan tinggi itu kita menfasilitasi peserta difabel. Kebetulan yang ikut tes ini difabelnya tidak berat. Seperti fasilitas lift dan kursi roda. Ini bentuk respon kepada orang yang dalam tanda kutip disebut

${ }^{25}$ Wawancara dengan Dekan Fakultas Syariah UIN Maulana Malik Ibrahim Malang, Dr. H. Roibin, M.HI., di Ruang Dekan Fakultas Syariah UIN Maulana Malik Ibrahim Malang, pada tanggal 19 Juli 2016, pukul $08.20 \mathrm{WIB}$ ${ }^{26}$ Ibid. 
orang lemah, meskipun mereka sendiri tidak mau dibilang lemah. ${ }^{27}$ Lebih lanjut beliau memaparkan bawah untuk kurikulum yang akan dipersiapkan untuk para difabel, harus bekerjasama dengan fakultas psikologi untuk merumuskan kurikulum yang pas dan tidak lupa adalah fasilitasnya juga dipersiapkan. Selain itu perlu juga ada volunter yang bisa medampingi dari mahasiswa difabel ini.

Berangkat Respon dari pengambil kebijakan di UIN Maulana Malik Ibrahim Malang mulai jajaran rektorat sampai dekanat sangat merespon baik tentang adanya UU No. 8 Tahun 2016 yang memberikan akses kepada para penyandang disabilitas untuk dapat memperoleh kesempatan untuk belajar di perguruan tinggi. Respon yang baik ini ditunjukkan dengan berbagai dukungan yang akan mereka berikan jika aturan dalam undang-undang ini benar diimplementasikan di lingkungan UIN Maulana Malik Ibrahim Malang.

Secara Normatif, UU No 8 Tahun 2016 tentang Penyandang Disabilitas dimana dalam Pasal 10 tentang hak pendidikan yaitu:

a. Hak pendidikan untuk Penyandang Disabilitas meliputi hak: mendapatkan pendidikan yang bermutu pada satuan pendidikan di semua jenis, jalur, dan jenjang pendidikan secara inklusif dan khusus;

b. Mempunyai Kesamaan Kesempatan untuk menjadi pendidik atau tenaga kependidikan pada satuan pendidikan di semua jenis, jalur, dan jenjang pendidikan;

c. Mempunyai Kesamaan Kesempatan sebagai penyelenggara pendidikan yang bermutu pada satuan pendidikan di semua jenis, jalur, dan jenjang pendidikan; dan

d. Mendapatkan Akomodasi yang Layak sebagai peserta didik

Kemudian dalam Pasal 42 dalam ayat (3) menyebutkan bahwa "tiap penyelenggara pendidikan tinggi wajib memfasilitasi pembentukan Unit Layanan Disabilitas”.

Untuk melaksankan amanah aturan tersebut di UIN maulana Malik Ibrahim Malang, tentunya tidak bisa secara langsung, akan tetapi memerlukan peran semua pihak dan peran bersama semua stake holder. Merekapun pada dasarnya menyetujui akan semua hak-hak yang sama untuk belajar di perguruan tinggi bagi penyandang difabel. Langkah awal yang bisa dilakukan yaitu mulai dari unsur pimpinan, sosialisasi dan juga rencana tindak lanjut harus segera dirancang. Mengingat implementasi dari undang- undang ini tidak secara serta merta bisa dilaksanakan dengan kondisi fasilitas, lingkungan, sumber daya manusia pendidik serta hal-hal lain yang masih harus diperbaiki dan dipersiapkan secara matang. Selain itu kesiapan dari segi kurikulum juga harus dipersiapkan. Hal ini karena melihat bahwa berbeda

${ }^{27}$ Wawancara dengan Wakil Rektor 1 UIN Maulana Malik Ibrahim Malang, Dr. H. Zainuddin, M.A., di Ruang Kerja Wakil Rektor 1 UIN Maulana Malik Ibrahim Malang, pada tanggal 18 Juli 2016, pukul 10.30 WIB 
jenis difabel maka akan berbeda pula kemampuan mereka baik kemampuan akademik dan kemampuan berinteraksi. Kemudia selain itu perlu adanya suatu unit layanan difabel dimana didalamnya ada seorang ahli dibidang difabel yang akan konsen dalam memberikan layanan bagi penyandang difabel yang akan belajar di UIN Maulana Malik Ibrahim Malang.

Kriteria universitas yang responsif terhadap penyandang disabilitas yang juga merupakan komponen dalam penilaian akreditasi perguruan tinggi, maka UIN Maulana Malik Ibrahim Malang dalam menggagas rencana pembangunan kampus 3 akan didesain untuk lebih responsif terhadap penyandang difabel dari segi bentuk bangunan dan fasilitasnya. Respon dari pimpinan atas adanya Undang-Undang ini juga sangat mendukung.

Berangkat dari penjelasan di atas, Respon yang positif dari Pimpinan UIN Maulana Malik Ibrahim Malang baik ditingkat Rektorat maupun di Tingkat Dekanat ini, Insyaallah akan mewujudkan UIN Maulana Malik Ibrahim Malang sebagai kampus Islam yang ramah terhadap difabel. Hal ini tentunya perlu kerjasa civitas akademika dan para stake holder terkait untuk mewujudkan itu, apalagi UIN Maulana Maulana Malik Ibrahim Malang sudah siap menjadi World Class University.

\subsection{Site Plan Kampus UIN Maulana Malik Ibrahim Untuk Mewujudkan Kampus Yang Ingklusi dalam Memberikan Akses Terhadap Penyandang Disabilitas Perspektif UU No. 8 Tahun 2016}

Perencanaan merupakan tahapan paling penting dari suatu fungsi manajemen, terutama dalam menghadapi lingkungan eksternal yang berubah dinamis. Dalam era globalisasi ini, perencanaan harus lebih mengandalkan prosedur yang rasional dan sistematis dan bukan hanya pada intuisi dan firasat (dugaan).

Terkait dengan diundangkannya UU No. 8 Tahun 2016 tentang Penyandang Disabilitas, Kabag Perencanaan UIN Maulana Malik Ibrahim Malang menjelaskan bahwa untuk pengembangan kampus yakni pembangunan kampus 3 UIN Maulana Malik Ibrahim Malang, dari pihak konstruksinya sudah memperhatikan masalah akses difabel ini. Beliau berharap UIN Maulana Malik Ibrahim Malang ingin mewujudkan sebagai kampus yang ramah difabel yakni dengan memberikan akses terhadap penyandang disabilitas. Kalau bagian konstruksi dikampus 1 dan 2 jika mau dirubah ramah difabel sepertinya kurang bisa, karena sudah terbentuk seperti ini, tapi itu karena perintah UU, maka kita akan melaksanakannya dengan cara bertahap. Mungkin yang dikampus 3 bisa dibuat perencanaan 
ulang yang bisa memberikan akses jika ada mahasiswa difabel di kampus ini. ${ }^{28}$ untuk gambar dan rencana site plan pebangunan gedung UIN 3 yang akan terletak di kota Batu adalah sebagaimana gambar di bawah ini:

\section{Gambar 1 \\ Site Plan Pembangunan Kampus 3 UIN Maulana Malik Ibrahim Malang}

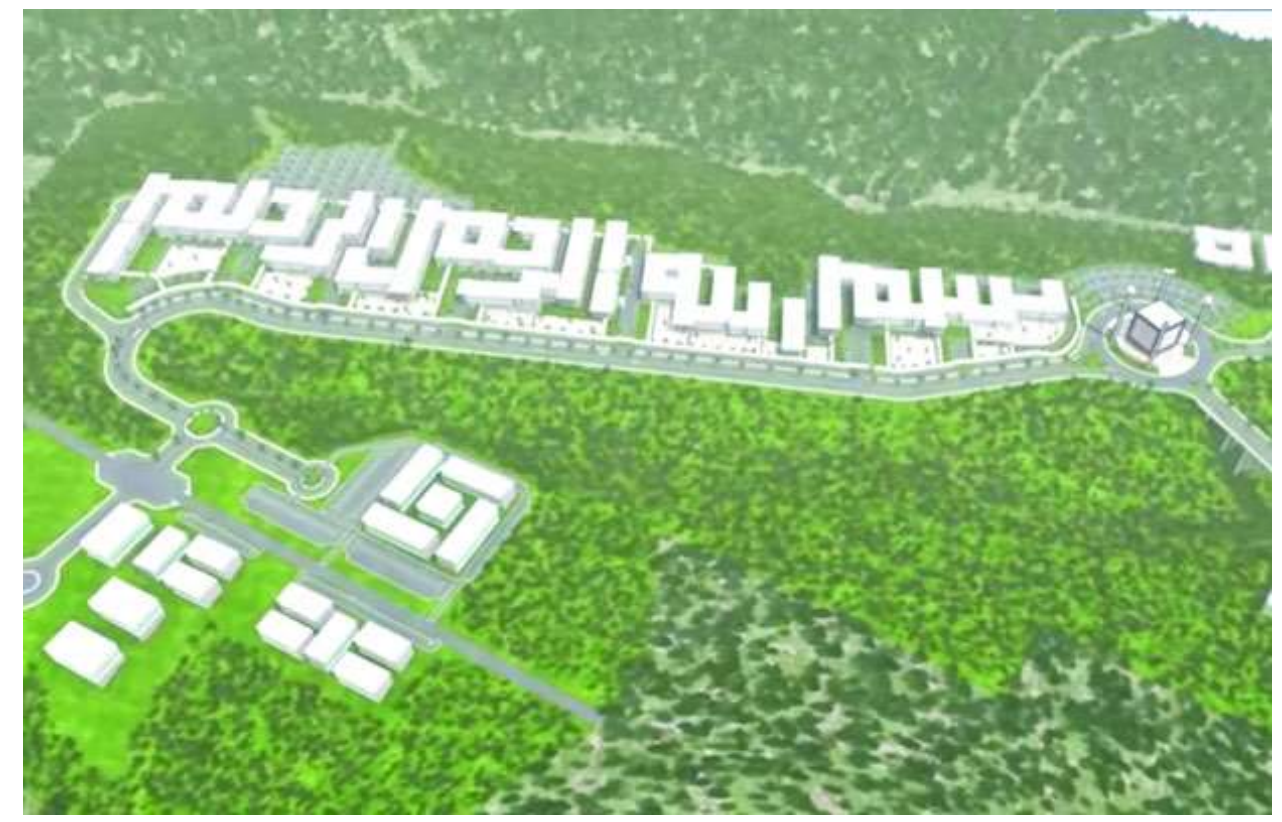

Rektor UIN Maulana Malik Ibrahim Malang menjelaskan bahwa, pengembangan kelembagaan kampus dengan pembangunan kampus 3 ini yang berlafal Basmalah, merupakan sebuah rencana besar yang insyaallah akan segera terwujud, terutama desainnya yang dirancang khusus dan unik sebagai perguruan tinggi Islam. Apalagi setelah diundangkannya UU No. 8 Tahun 2016 tentang Penyandang Disabilitas ini, pembangunan kampus 3 harus ramah difabel. ${ }^{29}$

Pengembangan kamus ke depan di UIN Maulana Malik Ibrahim Malang sudah mulai ditata dan dikelola dengan baik, terutama akses terhadap penyandang disabilitas sudah mulai disusun secermat mungkin. Bahkan menurut pak Kabag Perencanaan UIN Maulana Malik Ibrahim Malang, disaat membangun kampus 3 ini, ada beberapa perencanaan, yaitu perencanaan konstruksi, pengawasan dan fisik. Jika bangunan ini ramah difabel, maka harus

28 Wawancara dengan Kepala Bagian Perencanaaan UIN Maulana Malik Ibrahim Malang, Drs. Mohammad Ridwan, M.Pd., di Ruang Kerja Kepala Bagian Perencanaaan UIN Maulana Malik Ibrahim Malang, pada tanggal 18 Juli 2016, pukul 11.00 WIB.

${ }^{29}$ Wawancara dengan Rektor UIN Mulana Malik Ibrahim Malang, Prof. Dr. H. Mudjia Raharjo, M.Si., di Rumah Singgah Kampus II UIN Maulana Malik Ibrahim Malang, pada tanggal 18 Juli 2016 Pukul 10.00 WIB. 
ada perencanaan. Jika sudah memperhatikan itu, maka tahapan pengawasan dan konstruksi ini sudah mengikuti itu, di dalam perencanaan itu, ada tim teknis yang paham untuk masalah difabel ini, sehingga pembangunan kampus 3 itu benar-benar memberikan akses kepada penyandang disabilitas. ${ }^{30}$

Penyediaan sarana belajar yang ramah terhadap penyandang difabilitas adalah usaha pertama yang perlu dioptimalkan realisasinya. Perguruan tinggi perlu lebih awas terhadap kebutuhan mahasiswa difabel dalam mengakses materi-materi pembelajaran. Hal ini sangat penting, terutama bagi mahasiswa tunanetra yang cenderung lebih membutuhkan alat bantu yang berbeda dengan mahasiswa difabel lainnya. Keberadaan buku teks, diktat, dan slide presentasi yang umum digunakan di berbagai kampus cukup dapat mendukung mahasiswa difabel lainnya, seperti mahasiswa tunadaksa, tunarungu, ataupun tunawicara. Namun, bagi para mahasiswa tunanetra, keberadaan material pembelajaran yang cenderung bersifat visual tersebut tidak cukup membantu usaha belajar mereka. Untuk dapat membaca dan mengerjakan tugas, mereka membutuhkan alat-alat khusus seperti reglet dan stilus, papan bacaan, talking book, tape recorder, bahan cetak dengan tulisan berukuran besar, optacon untuk mengubah tulisan cetak menjadi dapat dikenali melalui perabaan, serta Kurzweil reading machine yang dapat menerjemahkan tulisan cetak ke dalam bentuk bunyi atau suara. $^{31}$

Mengenai sarana dan prasarana yang ramah difabel, seperti kelas dan laboratorium harus direncanakan dan disesuaikan. Menurut Wakil Dekan II Fakultas Psikologi UIN Maulana Malik Ibrahim, terkait dengan sarana dan prasarana harus ada penambahan lift di gedung yang berlantai karena alat eksperimen yang sulit di pindah- pindah yang ada di lantai 3, khusunya di fakultas psikologi saat ini, sehingga itu akan memudahkan bagi penyandang disabilitas dan memberikan akses terhadap mereka. ${ }^{32}$

\section{Kesimpulan}

Respon pengambil kebijakan di UIN Maulana Malik Ibrahim Malang dalam rangka memberikan akses terhadap penyandang disabilitas adalah mulai jajaran rektorat sampai

30 Wawancara dengan Kepala Bagian Perencanaaan UIN Maulana Malik Ibrahim Malang, Drs. Mohammad Ridwan, M.Pd., di Ruang Kerja Kepala Bagian Perencanaaan UIN Maulana Malik Ibrahim Malang, pada tanggal 18 Juli 2016 , pukul 11.00 WIB.

${ }^{31}$ F. Mangunsong, Psikologi dan Pendidikan Anak Berkebutuhan Khusus Jilid Kesatu, (Depok: LPSP3 UI, 2009), hlm. 23

${ }^{32}$ Wawancara dengan Wakil Dekan II Fakultas Psikologi UIN Maulana Malik Ibrahim Malang, Dr. Iin Tri Rahayu, M.Psi,. di ruang kerja Wakil Dekan II Fakultas Psikologi UIN Maulana Malik Ibrahim Malang, pada tanggal 19 Juli 2016, pukul 13.00 WIB. 
dekanat sangat merespon baik tentang adanya UU No. 8 Tahun 2016 yang memberikan akses kepada para penyandang disabilitas untuk dapat memperoleh kesempatan untuk belajar di perguruan tinggi. Respon yang baik ini ditunjukkan dengan berbagai dukungan yang akan mereka berikan untuk mewujudkan UIN Maulana Malik Ibrahim Malang menjadi kampus yang inklusi atau ramah terhadap mahasiswa penyandang disabilitas, bukti nyatanya adalah akan dimulai pada saat pembangunan kampus 3 UIN Maulana Malik Ibrahim Malang di Desa Tlekung Kota Batu Malang Jawa Timur.

Site plant kampus UIN Maulana Malik Ibrahim untuk mewujudkan kampus yang ingklusi dalam memberikan akses terhadap penyandang disabilitas perspektif UU No. 8 Tahun 2016 bahwa UIN Mulana Malik Ibrahim Malang sebagai institusi juga sudah menyusun perencanaan terutama terkait dengan pengembangan kampus. Penyusunan perencanaan pengembangan kampus UIN Maulana Malik Ibrahim yang ramah difabel akan dimulai pada saat membangun kampus 3. Ada beberapa tahapan perencanaan, yaitu perencanaan konstruksi, pengawasan dan fisik. Dalam tahapan perencanaan itu, site plan kampus UIN Maulana Malik Ibrahm Malang ini sudah dirumukan sebagai bangunan yang ramah difabel artinya akan memberikan akses terhadap penyandang disabilitas, yang dimulai dari pemberian sarana dan prasarana.

\section{DAFTAR PUSTAKA}

Agus Dwiyanto, Mewujudkan Good Governace Melalui Pelayanan Publik, (Yogyakarta: Gadjah Mada, 2005)

Amin Rahmanurrasyid, Akuntabilitas Dan Transparansi Dalam Pertanggung Jawaban Pemerintahan Daerah Untuk Mewujudkan Pemerintahan Yang Baik, (Tesis Tahun 2008)

Azyumardi Azra, Paradigma Membangun Karakter Bangsa Melalui Pendidikan, (Jakarta; Kompas, 2010)

A. Imron, Kebijakan Pendidikan di Indonesia: Proses, Produk, dan Masa Depannya, (Jakarta: Bumi Aksara, 1996)

Bambang Sunggono, Metodologi Penelitian Hukum, (Jakarta: Raja Grafindo Persada, 2003)

Bambang Waluyo, Penelitian Hukum Dalam Praktek, (Jakarta, Sinar Grafika, 2002)

Barbotte, E.Guillemin, F.Chau, N. Lorhandicap Group, Prevalence of Impairments, Disabilities, Handicaps and Quality of Life in the General Population: A Review of Recent Literature, Bulletin of the World Health Organization, Vol.79, No. 11, Tahun 2011 
C.S.T Kansil, Pengantar Ilmu Hukum dan Tata Hukum Indonesia, (Jakarta; Balai Pustaka, 1989)

Coleridge Peter, Pembebasan dan Pembangunan, Perjuangan Penyandang Cacat di NegaraNegara Berkembang, (Ygyakarta: Pustaka Pelajar, 2007)

D.M. Sidiq, "Mahasiswa Difabel di Perguruan Tinggi," dalam Sekar Ayu Aryani (ed.), Desain Pembelajaran Sensitif Difabel,( Yogyakarta: IIS PPS UIN, 2007)

Eko Riyadi, at.al, Vulnerable Groups: Kajian dan Mekanisme Perlindungannya, (Yogyakarta: PUSHAM UII, 2012)

Endang Warsiki dkk., Hubungan Antara Kecacatan Fisik Anak Dan Depresi Ibu Dari AnakAnak Tuna Daksa,(Surabaya: YPAC, 2003)

F. Mangunsong, Psikologi dan Pendidikan Anak Berkebutuhan Khusus Jilid Kesatu, (Depok: LPSP3 UI, 2009)

http://artikel2.com/site-plan/

Imam Suprayogo, Tarbiyah Ulul Albab: Dzikir, Fikr, dan Amal Shaleh, (Malang: Universitas Islam Negeri Malang, 2004)

Kamus Besar Bahasa Indonesia Pusat Bahasa ,Edisi Ke empat, (Departemen Pendidikan Nasional: Gramedia, Jakarta,2008).

Mas Achmad Daniri, Good Corporate Governance: Konsep Dan Penerapannya Dalam Konteks Indonesia, (Jakarta: Ray Indonesia, 2005)

Muhammad Effendi, Pengantar Psikopedagogik Anak Berkelainan, (Jakarta: Bumi Aksara, 2006)

Pendi, Responsibilitas Pelayanan Publik Dalam Kepemimpinan Integrative Terhadap Pembangunan Daerah, (Makassar: Skripsi Unhas: 2011)

Peter Mahmud Marzuki, Penelitian Hukum, (Jakarta: Kencana, 2005)

Rhona K.M Smith, Hukum Hak Asasi Manusia, (Yogyakarta: PUSHAM UII, 2008)

Ridwan Khairandy dan Camelia Malik, Good Corporate Governance: Perkembangan Pemikiran dan Implementasinya di Indonesia, (Yogyakarta: Kreasi Total, 2007)

Risnawati Utami, Konvensi Tentang Hak-Hak Penyandang Disabilitas: Dalam Perspektif Kebijakan Publik Di Indonesia, Makalah Untuk Intermediate Human Rights Training Bagi Dosen Hukum Dan HAM di Balikpapan, diselenggaakan atas Kerjasama PUSHAM UII dengan Norwegian Centere for Human Rights

Sapto Nugroho, Risnawati Utami, Meretas Siklus Kecacatan-Realitas Yang Terabaikan, (Surakarta: Yayasan Talenta, 2005) 
Soerjono Soekanto, Pengantar Penelitian Hukum, (Jakarta: Penerbit Universitas Indonesia Press, 1986)

Soetrisno Hadi, Metodologi Research, (Yogyakarta: Penerbit Andy Offset, 1995

T. Sutjihati Soemantri, Psikologi Anak Luar Biasa. (Bandung: Refika Aditama, 2006)

Terry L.Cooper, The Responsible Administrator : an approach to ethics for the administrative role, (United State : Jossey Bay, 1998)

UNESCO Bangkok, Teacing Children With Disabilities in Inclusive Settings, (Bngkok: UNESCO Bangkok, 2009)

Yayasan Mitra Netra. (2009, Maret). Halo Mitra. Retrieved Juni 30, 2010, from Yayasan Mitra Netra: http://www.mitranetra.or.id/default.asp? page=halo\&id=11

\section{PERATURAN PERUNDANG-UNDANGAN}

Undang-Undang Dasar Negara Republik Indonesia 1945

Undang-Undang Nomor 9 Tahun 1999 Tentang Hak Asasi Manusia,

Undang-Undang Nomor 28 Tahun 2002 tentang Bangunan Gedung,

Undang-Undang No. 20 Tahun 2003 tentang Sistem Pendidikan Nasional,

Undang-Undang Nomor 19 Tahun 2011 Tentang Pengesahan Hak-Hak Penyandang Disabilitas

Undang-Undang Nomor 12 Tahun 2012 tentang Perguruan Tinggi,

Undang-Undang Nomor Undang-Undang Nomor 8 Tahun 2016 Tentang Penyandang Disabilitas 